\title{
Think globally, act locally: the making of a mouse mammary gland
}

\author{
Lothar Hennighausen ${ }^{1}$ and Gertraud W. Robinson
}

Laboratory of Genetics and Physiology, N ational Institute of Diabetes, Digestive and Kidney Diseases, N ational Institutes of Health, Bethesda, M aryland 20892 USA

On a phylogenetic scale of organ development the mammary gl and is a recent acquisition. It was introduced 200 million years ago with the appearance of mammals to provide nourishment to the newborn in the form of milk. The mammary gland is characterized by a uni que dependence on hormonal signals for terminal differentiation, which is attained only after pregnancy. At the time of birth, the anlage consists of a few rudimentary ducts in the vicinity of the nipple. Pronounced ductal outgrowth and branching commences at puberty, and in pregnancy an expanded lobulo-alveolar compartment develops. Functional differentiation of the secretory epithelium coincides with parturition and large amounts of milk are produced and secreted during lactation. After weaning of the young, the entire alveolar epithelial compartment is remodeled to resemble a virgin-like state. With each pregnancy, a new round of lobulo-alveolar development occurs. During the past 100 years, intensive efforts have been made to understand the endocrine control of mammopoiesis and lactogenesis. Classical research on endocrine ablated animal s firmly establ ished that ovarian steroids and pituitary peptide hormones are mandatory and sufficient for breast development and lactation. In 1900, Halban first established that mammary growth is controlled by the ovary (Hal ban 1900). Hedemonstrated that ovariectomy caused mammary regression, and that transplanted ovaries prevented the castration atrophy of mammary glands. Twenty-eight years later, Stricker and Grueter induced mammary development and milk secretion artificially in castrated virgin rabbits by injection of pituitary extract (Stricker and Grueter 1928). In 1933, Riddle, Bates, and Dykshorn purified the respective pituitary hormone (Riddle et al. 1933) and named it prolactin(PRL).

In the last several years, the ability to delete genes from the mouse genome has allowed us to identify genetic components of mammary gland devel opment. M olecular insight into the underlying genetic framework and signal ing networks of the developing tissue has been gained through experimental manipulations of tissues from wild-type and knockout mice. Two distinct, yet

${ }^{1}$ Corresponding author.

E-MAIL mammary@nih.gov; FAX (301) 496-0839. braided, developmental concepts have unfolded. First, discrete signaling networks activated by systemic endocrine hormones induce mammopoiesis. Secondly, some of these signals are relayed through reciprocal interactions between the epithelium and the stroma. Table 1 contains those genes whose elimination from the mouse genome results in impaired mammary gland development. Among these genes are some of the "usual suspects" but also some previously unidentified players. Each mutation affects specific and distinct aspects of mammary devel opment. These knockout mice not only confirmed the involvement of hormonal signaling but also provided tools to identify the tissue compartment that receives and executes these signals.

\section{Morphogenesis}

Functional development of the mammary gland proceeds in distinct stages (Fig. 1) that are defined fundamentally by the hormonal status of the animal. The mammary anlage is established during fetal development, ductal elongation and branching is obtained primarily after the onset of puberty, alveolar proliferation occurs during pregnancy, and functional differentiation is accomplished with parturition and lactation.

Before puberty and the onset of gonadal hormone se cretion, the mammary ducts elongate into the mammary fat pad at a rate that is in pace with the overal I growth of the animal (Fig 1a). Accelerated ductal extension and branching commences with the start of puberty at about 4 weeks of age when large cl ub-shaped terminal end buds (TEB) appear (Fig. 1b,c), and ceases when the fat pad is laced with a ductal tree (Fig. 1d). The TEB is a specialized structure at the end of growing ducts that consists of two histologically distinct cell types. Thebody cells, give rise to mammary epithel ial cells, and the cap cells, which are the precursors of myoepithelial cells (Humphreys et al. 1996). Ductal arborization is initiated from the highly proliferative TEBs (Daniel and Silberstein 1987). Ductal morphogenesis and lumen formation is accomplished by a highly regulated process of cell proliferation and death in the TEB (Bresciani 1968; Humphreys et al. 1996). The ducts, which will ultimately serve as channels for milk transport during lactation, are lined by a single layer of luminal epithelial cells. The myoepithelial cells form a 
Table 1. Knockout mice and natural mutants that exhibit a mammary gland phenotype

The making of a mammary gland

\begin{tabular}{|c|c|c|c|}
\hline $\begin{array}{l}\text { Hormones, } \\
\text { growth } \\
\text { regulators, and } \\
\text { receptors }\end{array}$ & $\begin{array}{l}\text { Transcription } \\
\text { factors }\end{array}$ & Cell cycle & Others \\
\hline $\begin{array}{l}\text { Prolactin (PRL) } \\
\text { (1) }\end{array}$ & $\begin{array}{l}\text { Progesterone R } \\
\text { (PR) (6) }\end{array}$ & cyclin D1 (12) & LAR (13) \\
\hline $\begin{array}{l}\text { Prolactin R } \\
\quad(\text { PRLR) (2) }\end{array}$ & $\begin{array}{l}\text { Estrogen R (ER) } \\
\text { (7) }\end{array}$ & & \\
\hline Oxytocin (3) & Stat5a (8) & & \\
\hline InhibinßB (4) & A-myb (9) & & \\
\hline \multirow[t]{2}{*}{ CSF-1 (5) } & mf3 (10) & & \\
\hline & C/EBP $\beta$ (11) & & \\
\hline
\end{tabular}

References: (1) Horseman et al . (1997); (2) Ormandy et al . (1997); (3) Wagner et al. (1997b); (4) Ormandy et al. (1997); (5) Pollard and Hennighausen (1994); (6) Lydon et al. (1995); (7) Lubahn et al. (1993); (8) Liu et al. (1997); (9) Toscani et al. (1997); (10) Labosky et al. (1997); (11) Robinson et al., Seagroves et al. (both unpubl.); (12) Sicinski et al. (1995); (13) Schaapveld et al. (1997).

sleeve around the primary ducts and become discontinuous around secondary and tertiary ducts and the TEBs. During pregnancy additional ductal branching occurs (Fig. 1e) and extensive lobulo-alveolar proliferation gradual ly results in the complete filling of the fat pad at parturition (Fig. 1f). Cell division occurs in both the ductal and alveolar cell population throughout pregnancy, and persists through the early phase of lactation.

\section{Hormonal regulation}

Both the role of systemic hormones and the influence of the stroma on mammary epithelial cells have been recognized for some time (Sakakura 1987, 1991). However, only now through the availability of knockout mice have we been able to dissect indi vidual steps in the pathways of the translation of hormonal signals into morphogenetic and developmental events. Two unique aspects of mammary gland development have greatly ai ded in exploiting these knockout animals to el uci date the specific roles of the epithelium and the stroma. First, the mammary gland develops predominantly in the postpartum mammal. Therefore, an entire developmental program, mimicking embryonic devel opment of other organs, can be viewed and followed in postpartum animals. This characteristic has several ramifications; the tissue can be easi ly manipulated, and reasonable amounts of tissue are available for analysis. Furthermore, genetic manipulations whose consequences in other tissues would result in lethal ity, can be studied. Second, it is possible to generate chimeric glands composed of tissues from knockout and wild-type animals. Because the epithelium penetrates the fat pad only in pubertal animals it can be removed surgically before this stage. A small piece of epithelium from another animal can then be implanted into the "cleared" fat pad and will develop there (DeOme et al. 1958). Alternatively, epithelium and stroma can be separated enzymatical ly and recombined. The assembled tissues can also be grown as grafts under the kidney capsule of appropriate hosts (Cunha 1994; Cunha et al. 1997).

\section{Estrogen}

Ductal el ongation seen in the first few days after birth originates from a few small TEBs and is probably the result of residual effects of maternal and fetal hormones. Although ductal growth is sl ow for the first 2-3 weeks, it accel erates greatly with puberty. Thus ductal outgrowth and, in part, al veolar proliferation is controlled by ovarian steroid hormones (Daniel and Sil berstein 1987). Regression of both ducts and alveoli was observed upon ovariectomy, and could be reinduced after treatment with estrogen or progesterone (Mixner and Turner 1942). Studies in mice from which the estrogen receptor (ER)- $\alpha$

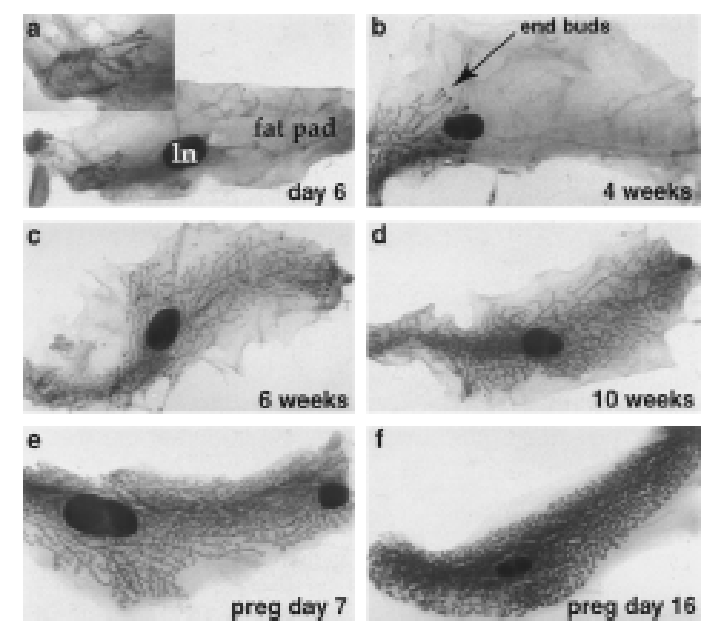

Figure 1. Whole-mount analysis of mouse mammary glands at different stages of development. (a) 6 days; (b) 4 weeks; (c) 7 weeks; (d) 12 weeks; (e) early pregnancy; (f) late pregnancy. In, lymph node. Theinguinal (no. 4) gland was excised, mounted on a glass slide, fixed, and stained with Carmine Red. The lymph node serves as a convenient reference point to evaluate ductal outgrowth. In the 6-day-old mouse the mammary fat pad is largely empty (a), and the few rudimentary ducts emerging from the nipple are proximal to the lymph node (inset in a). Ductal el ongation and branching commences with puberty at $\sim 4$ weeks (b). Prominent terminal end buds (TEBs) are visible (arrow in b), and ducts extend beyond the lymph node. The TEBs serve as the staging ground for ductal el ongation, which is the result of controlled proliferation and apoptosis. At 6 weeks the ducts have reached the border of the fat pad with some remaining TEBs (c). Additional branching occurs in the mature virgin, and at 12 weeks the fat pad is laced with a network of ducts (d). At this stage the TEBs have disappeared. Proliferation of mammary secretory epithelial cells during pregnancy leads to the formation of an alveolar compartment that produces milk during lactation. Extensive alveolar proliferation occurs at mid-pregnancy (e), and at parturition the mammary fat pad is completely filled with the secretory lobulo-al veolar structures (f). 
gene had been del eted (ERKO mice) have confirmed that estrogen is required for ductal outgrowth (Korach et al. 1996), and have shed light on the underlying molecular mechanisms. Analysis of the mammary glands of the ERKO females at 4 months of age revealed a primitive ductal rudiment devoid of TEBs, whereas a fully developed ductal tree was seen in wild-type siblings. To determine whether estrogens elicit epithelial mitogenesis directly through epithelial ER or indirectly through ERpositive stromal cells, mammary tissue from adult ERdeficient mice and wild-type mice were used to produce tissue recombinants containing ER in epithelium and/or stroma, or lacking ER altogether. Tissue recombinants were grown as subrenal capsule grafts in intact female nude mice, and the hosts were treated with estradiol (E2) after ovariectomy. Ductal outgrowth was dependent on the presence of ER in the stroma but not in the epithelium. These data suggest that, although ER is detected both in the epithelium and the stroma, epithelial mitogenesis induced by E2 is a stromally mediated event and that epithelial ER is neither necessary nor sufficient for E2-induced mammary epithelial proliferation (C unha et al. 1997).

\section{Progesterone}

Adult femal es lacking the progesterone receptor (PR) displayed severe defects in reproductivetissues (Lydon et al . 1995). This demonstrates the role of progesterone as a plei otropic coordinator of reproductive events. Because PR-deficient mice were infertile attributable to a failure of ovulation and luteinization, mammary development was studied by treatment of ovariectomized PR-deficient and control mice with estrogen and progesterone (Lydon et al. 1995). In the absence of exogenous estrogen and progesterone, the rudimentary ductal tree in PR-deficient mice was similar to that in control mice. However, after hormone treatment, extensive arborization of the ductal tree and some al veolar devel opment was observed in control mice, but virtually absent in the PR-deficient mice. Unlike the ER, whose presence is required in the stroma, the function of the PR is mainly linked to the epithelium. Reciprocal transplantation experiments demonstrated that the absence of PR in transplanted donor epithelium but not in the stroma, prevented normal Iobulo-alveolar development in response to estrogens and progesterone. However, the absence of PR in the recipient stroma revealed that stromal PR may be required for ductal outgrowth (Humphreys et al. 1997).

Activins/inhibins and other members of the TGF $\beta$ family

Inhibins and activins are members of the TGF $\beta$ family and are important regul ators in reproductive organs (Vale et al. 1994). A specific function for the activin and inhibin $\beta B$ subunit was identified for the mammary gland. Mice deficient in the inhibin $\beta B$ gene exhibit retardation of ductal elongation and alveolar morphogenesis during puberty and pregnancy, respectively. Mam- mary transplantation experiments demonstrated a localized defect in the gland that was associated with the stroma. Ductal elongation and alveolar proliferation and differentiation were severely curtailed in inhibin $\beta B$-deficient stroma (Robinson and Hennighausen 1997). Abnormal morphology of TEBs infers a disturbance in the balanced cell proliferation and cell death in this structure as the cause of the developmental defect. Although the mechanisms through which activins/inhibins exert their function are presently not clear, their effect on mammary epithelial cells make them good candidates for local mediators of hormonal signals. Other members of the super-family of TGF $\beta$ genes most likely also play a role in mammopoiesis. Recent results with overexpression of a dominant negative receptor type II for TGF $\beta$ in mammary epithelial cells show that an interception of proper TGF $\beta$ signaling leads to mammary hyperplasia (Gorska et al. 1998). Furthermore, several bone morphogenetic proteins (BMPs) are expressed in many sites of epithelial mesenchymal interactions and may be identified as important components in mammary gland development once the appropriate knockout models will be available for analysis.

\section{Prolactin}

Prolactin signaling is essential for the proliferation and functional differentiation of Iobulo-alveolar structures during pregnancy (Topper and Freeman 1980). Gene deletion experiments have surveyed four independent components of the prolactin pathway, the ligand itself (Horseman et al. 1997), the receptor (Ormandy et al. 1997), as well as Stat5a (Liu et al . 1997) and Stat5b (Udy et al. 1997). PRL is synthesized predominantly in lactotrophic cells of the anterior pituitary of vertebrates. Tissue culture experiments had demonstrated that binding of PRL to its receptor (PRLR) leads to receptor dimerization and the activation of the Janus kinase 2 (JAK2), Fyn, and the mitogen-activated protein (MAP) kinase. In vivo experiments have now taught us that PRL signaling in the mammary gland largely operates through the JAKST AT pathway (Liu et al. 1997). JAK2 is recruited to the PRLR and phosphorylates predominantly the two Stat5 isoforms (5a and 5b) on tyrosine 694. Both Stat5a and 5b bind to and induce transcription of genes containing $\gamma$ interferon activation sites (GAS). The establishment of mice deficient in the different components has now provided formal proof of this signal ing pathway. Because the PRLR is expressed in multiple organs of the developing fetus, and Stat5a and Stat5b are operative in many other cytokine signaling pathways, it was a surprise that mice deficient in any of these signaling molecules were born and survived until adul thood. Defects were confined to a few tissues and specific physiological conditions. Most noticeably, mammary development was severely impaired in the absence of PRL, the PRLR, and Stat5a, but not Stat5b (J. Ihle and S. Teklund, in prep.).

Similar to PR-deficient mice, del etion of the PRL gene resulted in curtailed ductal arborization in adult virgins (Horseman et al. 1997), suggesting a role in ductal mor- 
phogenesis al ready during puberty. However, as PRL-deficient mice do not ovulate, the observed effect could al so be indirect. Because PRL-deficient mice are infertile, the role of PRL during pregnancy and lactation has not been assessed. It is concei vable that signal ing by the two pl acental lactogens may be compensating for the absence of PRL during pregnancy.

The importance of PRLR-mediated signaling in mammary gl and devel opment is illustrated by the finding that femal es with only one intact PRLR allel e failed to lactate after their first pregnancy (Ormandy et al. 1997). Epithelial cell proliferation and differentiation during pregnancy appears to be dependent on a threshold level of PRLR that cannot be obtained with just one functional allele. However, mammary gl and development after the second pregnancy or in older females was sufficient for successful lactation, demonstrating that continued hormonal stimuli will eventually lead to the development of a functional gland. Females lacking both PRLR alleles were infertile due to a failure of implantation of the embryos. Implantation and pregnancies were obtained after administering progesterone, but mammary development was severely curtailed and dams failed to lactate ( $P$. Kelly, pers. comm.).

Stat5a and Sta5b have a similarity of $96 \%$ and exhibit a superimposable pattern of expression during pregnancy and lactation (Liu et al. 1996). It was, therefore, not expected that mice deficient in either Stat5a or Stat5b would present distinct developmental lesions. The most noticeable phenotype of Stat5a-deficient mice is their inability to lactate because of a failure of the gland to develop fully and to undergo functional differentiation during pregnancy (Liu et al. 1997). Remarkably, Stat5b protein levels, and even more pronounced, the extent of its phosphorylation, were greatly reduced in Stat5a-deficient mammary tissue indicating that efficient phosphorylation of Stat5b requires the presence of Stat5a ( $\mathrm{Liu}$ et al . 1997). The mechanism for this is not clear, but it is possible that activated Stat5a is necessary to achieve and maintain a state of cell differentiation needed for full activation of Stat5b. Stat5b-deficient mice exhibited a different phenotype affecting liver gene expression and body growth rates. In addition, their fertility was severely compromised (Udy et al. 1997). However, those mice that maintained their pregnancy, delivered normal sized litters and were able to lactate (J. Ihle and S. Teklund, in prep.). Although the biochemical features of Stat5a and Stat5b are indistinguishable in most, if not all, tissue culture settings, both proteins have distinct functions in vivo.

\section{Colony-stimulating factor-1}

A natural mutant, op (osteopetrosis), in the gene encoding macrophage colony-stimulating factor-1 (CSF-1) has been identified. Although the primary phenotype in these mice is an absence of functional osteoclasts and a failure in tooth eruption, lactation is also severely impaired (Pollard and Hennighausen 1994). A reduced ductal growth during pregnancy, precocious devel opment of lobules, and absence of milk secretion is observed in these mice (Pollard and Hennighausen 1994).

\section{Oxytocin}

Physiological studies have ascribed pleiotropic roles to oxytocin (OT). However, OT-deficient mice have displayed a specific and exclusive role of OT for milk ejection and postpartum development. OT induces the contraction of the cage of myoepithelial cells surrounding the alveol $i$ and thereby induces milk ejection. In the absence of OT, milk fails to be ejected (Young et al. 1996; $\mathrm{N}$ ishimori et al. 1996), which in turn leads to rapid involution of the gland (Wagner et al. 1997a). Thus, OT is not only necessary for postpartum milk ejection but al so for alveolar cell proliferation. In a similar way, the absence of the winged helix transcription factor $\mathrm{Mf3}$ disturbs mammary function and milk ejection. M orphogenesis of the gland appears normal but lactation is inhibited and can be rescued by injections of OT (Labosky et al. 1997).

\section{Signaling within the cell}

Although distinct morphogenic and lactogenic roles have been assigned to systemic hormones and local growth factors, the cascades and networks of signals leading to a nuclear response and subsequent activation of developmental programs are in many cases poorly understood. It is concei vable that extracell ular signal s el i cit different responses in the different cell populations of the mammary gland and the read out depends on the cellular context. Even though particular target genes for the control of growth and differentiation have not been characterized, it is safe to predict that transcription factors and components of the cell cycle machinery are mandatory mediators of these events. Gene deletion experiments performed for reasons other than studying the mammary gland may have uncovered some true targets by serendipity. These include the transcription factors $A-m y b$ and C/EBP $\beta$ and the cyclin D1 gene. Females carrying del etions in the A-myb (Toscani et al . 1997) and C/EBP $\beta$ (G.W. Robinson, E. Sterneck, P.F. Johnson, and L. Hennighausen; T.N. Seagroves and J.M. Rosen; both unpubl.) genes exhibit severely curtailed alveolar development and differentiation during pregnancy. Both of these transcription factors are expressed in many different tissues yet their absence is manifest in only alimited number of cell types. The case of C/EBP $\beta$ is particularly intriguing. The promoter of the $\beta$-casein gene contains a $\mathrm{C} / \mathrm{EBP} \beta$ site and the expression of C/EBP $\beta$ in the mammary gland is developmentally regulated (Raught et al. 1995). It is not known whether the lesion in the C /EBP $\beta$ knockout mice results from a reduction in cell proliferation or enhanced cell death. The findings strongly imply that $C / E B P \beta$ plays a dual role in epithelial cell regulation and $\beta$-casein gene expression. Interestingly, mice bearing a deletion of the cyclin D1 gene fail to form functional alveoli during pregnancy (Fantl et al. 1995; Sicinski et al. 1995). Cyclin D1 is expressed in most tissues but its 
levels are higher in mammary epithelial cells. It was shown recently that cyclin D1 interacts with ER to activate transcription (Zwijsen et al. 1997). The different phenotypes in ERKO and cyclin D1-deficient glands indicate, however, that the effects of E2 on ductal elongation are independent of cyclin D1.

M ore puzzling is the role of intracellular phosphatases in the control of lactogenesis. N ormal mammary morphogenesis but impaired function is observed in the absence of the cytoplasmic phosphatase LAR (Schaapveld et al. 1997). Although the molecular basis of this defect is unclear, it has been shown that LAR is found in focal adhesion sites. This may ill ustrate the importance of signaling from the extracellul ar environment and neighboring cells in mammopoiesis. It is to be expected that this and other phosphatases are instrumental in the regulation of the JAK-STAT cascade or other pathways necessary for normal mammary development.

These examples of specific lesions resulting from the absence of ubiquitously expressed genes in only a few cell types may indicate combinatorial regulation mechanisms that utilize shared components leading to unique responses in mammary epithelial cells.

\section{Systemic homones and inductive epithelial-stromal interactions control mammary development}

The concept of organogenesis as an inductive event dates back to 1901 when Hans Spemann demonstrated that lens development is dependent on inductive signal s from the optic cup to the presumptive head ectoderm (Spemann 1901). More recently the mammary gland has emerged as a rich developmental model that depends on epithelial-stromal interactions, both in the embryo and postnatally. By now more than ten mutants affecting mammary development have been generated using reverse genetics. From the analysis of these mutants a model for mammary devel opment has emerged that can serve as a reference point for future studies. With the onset of puberty, rapid ductal el ongation and arborization occurs as a result of ovarian estrogens. Balanced cell proliferation and cell death within the TEBs lead to the penetration of the newly formed ducts through the stromal fat pad. Although the ER is present in both stromal and epithelial cells, it is required only in the stroma for proper ductal development. The stroma-derived mediator that signals epithelial cell proliferation is still elusive, but may well fall into the TGF $\beta$ family. The proliferative response in the epithelial cells includes the transcription factor $C / E B P \beta$ as indicated by the absence of normal ductal arborization in the absence of this gene. During pregnancy additional systemic, local and intracellular signals are requi red for alveol ar proliferation and differentiation. Although progesterone signaling controls alveolar proliferation, PRL signaling to a great extent directly controls epithelial cell differentiation. Progesterone-induced ductal arborization is mediated directly through epithelial receptors in addition to "learned adaption" through the stroma. As the ducts penetrate the fat pad the stromal cells respond to signals from the epithelium and become competent to support additional ductal and alveolar development. A similar situation is encountered in the development of the ure ter (Vainio and Mueller 1997) were signals from the ureter epithelium pattern the surrounding mesenchyme. Such feedback signal ing can lead to autoregul atory loops further promoting stromal and epithelial maturation. Locally secreted growth factors are candidates to act as mediators of the stromal PR-dependent signal. Members of the TGF $\beta$ family, CSF-1, and/or EGF may be involved. Recent experiments with EGF receptor (EGFR)-deficient mice have demonstrated that the stromal EGFR is required for ductal development ( $Z$. Werb and G. Cunha, pers. comm.). Thus, EGF and activins are prime candidates to convey systemic signals between stroma and epithelium. Less clear are some of the signaling events leading to the functional differentiation of the epithelium. In particular, the roles which CSF-1 (Pollard and Hennighausen 1994) and LAR (Schaapveld et al. 1997) play in the mammary gland need to be defined.

\section{Understanding development through the advance of functional genomics}

Our model is far from complete, and it will be scrutinized and modified as new informat on becomes available. In particular, it will be necessary to further define reciprocal and adaptive signaling between the epithelium and stroma. This not only includes the identification of primary and secondary target genes in the different signaling pathways, but also their genetic manipulation.

A pursuit of two distinct strategies will establish the genetic and functional framework for a more comprehensive developmental model. The genomics approach will identify putative control genes, and gene manipulation in conjunction with tissue transplants will eval uate their physiologic role. A three-pronged genomics approach is part of the Mammary Genome Anatomy Project (MGAP). Large-scale sequencing of normalized cDNA libraries from different stages of normal mouse mammary gl and devel opment is being pursued. Information emerging from this will establish the basic genetic makeup during normal mammopoiesis. This advance is complemented through the analysis of gene expression of different knockout mice. Differential cDNA libraries may identify target genes of individual pathways that have been disrupted in mouse models. Finally, laser capture microscopy (LCM) combined with large scale sequencing will establish the genetic fingerprint image of particular cell cluster. Although this strategy will be informative, it will not detect specific protein-based regulatory events. A classic example is Stat5a, a critical mediator of mammary development whose activity is controlled through phosphorylation. The levels of Stat5a RN A and protein do not change significantly during the course of puberty, pregnancy, and lactation. However, PRL-mediated tyrosine phosphorylation, and thereby transcriptional activity, is sharply induced during pregnancy. Thus, to detect such regulatory events it will be 


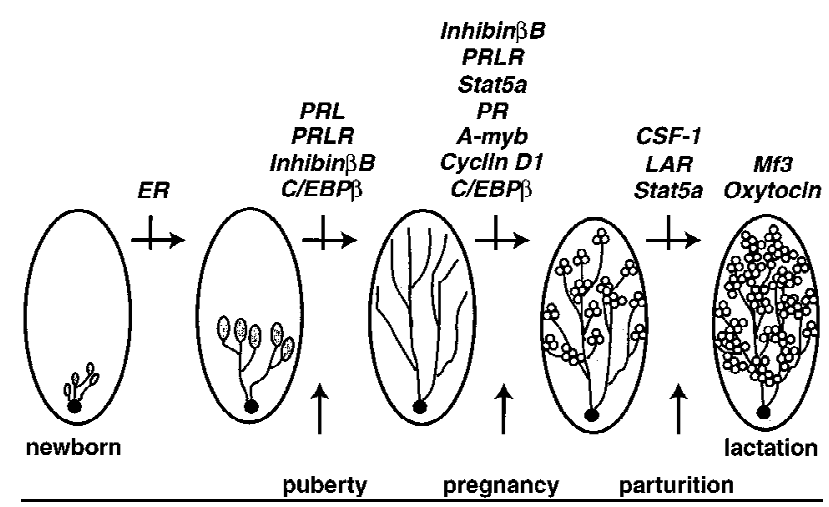

Figure 2. Diagram defining distinct steps during mouse mammary gland development and the gene products required to proceed through developmental programs. (ER) Estrogen receptor (Lubahn et al. 1993); (PRL) Prolactin (Horseman et al. 1997); (PRLR) Prolactin receptor (Ormandy et al. 1997), inhibin $\beta B$ (Robinson and Hennighausen 1997), C/EBP $\beta$ (G.W. Robinson, E. Sterneck, P.F. Johnson, and L. Hennighausen, in prep.); (Stat5a) Signal transducer and activator of transcription (Liu et al. 1997); (PR) Progesterone receptor (Lydon et al. 1995), A-myb (Toscani et al. 1997); cyclin D1 (Fantl et al. 1995; Sicinski et al. 1995); (CSF-1) macrophage specific colony stimulating factor 1 (Pollard and Hennighausen 1994); LAR (Schaapveld et al. 1997); Mf3 (Labosky et al. 1997); oxytocin (Wagner et al. 1997a).

necessary to develop large-scal e screening assays that detect post-translational modifications.

$\mathrm{N}$ ext on the agenda will be the assignment of physiological relevance to putative control genes. Traditional gene deletion technology based on homologous recombination inactivates genes in the entire animal and can result in early embryonic lethality, which in turn prohibits studies of mammary development. Furthermore, this technology does not permit the dissection of indirect effects on mammary development and the temporal and spatial assignment of gene function. For example, it does not provide information on time windows during which a particular gene product is needed. Innovative approaches to address these questions include targeting specific cell types in the mammary gland during defined time windows. Recent advances using time-sensitive gene control systems (Ewald et al. 1996) and Cre-mediated tissue-specific gene del etion systems (Wagner et al . 1997b) provide exciting new opportunities. In addition to whole animal studies, the use of organ culture systems should be pursued. It is possible to mimic distinct aspects of mammary gland development and function in vitro using whole tissue organ cultures. Although we are now able to draw an overall blueprint of mammary gland development (Fig. 2), it is still a rough draft and new pieces will be added at an accelerating pace to this exciting developmental puzzle.

\section{Acknowledgments}

We thank the members of the Hennighausen laboratory for helpful discussions and Patricia Dierisseau for Figure 1.

\section{References}

Bresciani, F. 1968. Topography of DNA synthesis in the mammary gland of the $\mathrm{C} 3 \mathrm{H}$ mouse and its control by ovarian hormones: An autoradiographic study. Cell Tissue Kinet. 1: 51-63.

Cunha, G.R. 1994. Role of mesenchymal-epithelial interactions in normal and abnormal development of the mammary gland and prostate. Cancer 74: 1030-1044.

Cunha, G.R., P. Young, Y.K. Hom, P.S. Cooke, J.A. Taylor, and D.B. Lubahn. 1997. Elucidation of a role for stromal steroid hormone receptors in mammary gland growth and development using tissue recombinants. J. Mamm. Gland Biol. Neoplasia 2: 393-402.

Daniel, C.W. and G.B. Sil berstein. 1987. Postnatal development of the rodent mammary gland. In The mammary gland: Development, regulation, and function. (ed. M.C. N eville and C.W. Daniel), pp. 3-36. Plenum Press, N ew York, NY.

DeOme, K.B., L.J. Faulkin, Jr., H.A. Bern, and P.E. Blair. 1959. Development of mammary tumors from hyperplastic alveolar nodules transplanted into gl and-free mammary fat pads of female C 3H mice. Cancer Res. 19: 515-520.

Ewald, D., M. Li, S. Efrat, G. Auer, R.J. Wall, P.A. Furth, and L. Hennighausen. 1996. Time-sensitive reversal of hyperplasia in transgenic mice expressing SV40 T antigen. Science 273: 1384-1386.

Fantl, V., G. Stamp, A. Andrews, I. Roswell, and C. Dickson. 1995. Mice lacking cyclin D1 are small and show defects in eye and mammary gland development. Genes \& Dev. 9: 2364-2372.

Gorska, A.E., H. Joseph, R. Derynek, H.C. M oses, and R. Serra. 1998. Dominant-negative interference at the TGF- $\beta$ type II receptor in mammary gland epithelium results in alveolar hyperplasia and differentiation in virgin mice. Cell Growth Differ. (in press).

Halban, J. 1900. Die innere Sekretion von Ovarium und Placenta und ihre Bedeutung fuer die Function der M ilchdruese. Mschr. Geburtsh. Gynaek. 12: 496-503.

Horseman, N., W. Zhao, E. M ontecino-Rodriguez, M. Tanaka, K. N akashima, S. Engle, F. Smith, E. Markoff, and K. Dorshkind. 1997. Defective mammopoiesis, but normal hematopoi esis, in mice with a targeted disruption of the prolactin gene. EMBO J. 16: 6926-6935.

Humphreys, R.C., M. Krajewska, S. Krnacik, R. Jaeger, H. Weiher, S. Krajewski, J.C. Reed, and J.M. Rosen. 1996. A poptosis in the terminal endbud of the murine mammary gland: a mechanism of ductal morphogenesis. Development 122: 4013-4022.

Humphreys, R.C., J. Lydon, B.W. O'Malley, and J.M. Rosen. 1997. Mammary gland development is mediated by both stromal and epithelial progesterone receptors. Mol. Endocrinol. 11: 801-811.

Korach, K.S., J.F. Couse, S.W. Curtis, T.F. Washburn, J. Lindzey, K.S. Kimbro, E.M. Eddy, S. Migliaccio, S.M. Snedeker, D.B. Lubahn, D.W. Schomberg, and E.P. Smith. 1996. Estrogen receptor gene disruption: molecular characterization and experimental and clinical phenotypes. Recent Prog. Horm. Res. 51: 159-186.

Labosky, P.A., G.E. Winnier, T.L. Jetton, L. Hargett, A.K. Ryan, M.G. Rosenfeld, A.F. Parlow, and B.L. Hogan. 1997. The winged helix gene, $\mathrm{Mf3}$, is required for normal development of the diencephal on and midbrain, postnatal growth and the milk-ejection reflex. Development 124: 1263-1274.

Liu, X., G.W. Robinson, and L. Hennighausen. 1996. Activation of Stat5 and Stat5b by tyrosine phosphorylation is tightly linked to mammary gland differentiation. Mol. Endocrinol. 
10: 1496-1506.

Liu, X., G.W. Robinson, K.U. Wagner, L. Garrett, A. WynshawBoris, and L. Hennighausen. 1997. Stat5a is mandatory for adult mammary gland development and lactogenesis. Genes \& Dev. 11: 179-186.

Lubahn, D.B., J.S. M oyer, T.S. Golding, J.F. Couse, K.S. Korach, and O. Smithies. 1993. Alteration of reproductive function but not prenatal sexual devel opment after insertional disruption of the mouse estrogen receptor. Proc. Natl. Acad. Sci. 90: 11162-11166.

Lydon, J.P., F.J. DeM ayo, C.R. Funk, S.K. Mani, A.R. Hughes, C.A. Montgomery, G. Shyamala, O.M. Conneely, and B.W. O'M alley. 1995. Mice lacking progesterone receptor exhibit pleiotropic reproductive abnormalities. Genes \& Dev. 9: 2266-2278.

Mixner, J. and C. Turner. 1942. Role of estrogen in the stimulation of Iobule-alveolar growth by progesterone and by the mammogenic lobule-alveolar growth factor of the anterior pituitary. Endocrinology 30: 591-597.

Nishimori, K., L.J. Young, Q. Guo, Z. Wang, T.R. Insel, and M.M. Matzuk. 1996. Oxytocin is required for nursing but is not essential for parturition or reproductive behavior. Proc. Natl. Acad. Sci. 93: 11699-11704.

Ormandy, C.J., A. Camus, J. Barra, D. Damotte, B. Lucas, H. Buteau, M. Edery, N. Brousse, C. Babinet, N. Binart, and P.A. Kelly. 1997. Null mutation of the prolactin receptor gene produces multiple reproductive defects in the mouse. Genes \& Dev. 11: 167-177.

Pollard, J.W. and L. Hennighausen. 1994. Colony stimulating factor 1 is required for mammary gland development during pregnancy. Proc. Natl. Acad. Sci. 91: 9312-9316.

Raught, B., W.S. Liao, and J.M Rosen. 1995. Developmentally and hormonally regulated CCAAT/enhancer-binding protein isoforms influence beta-casein gene expression. Mol. Endocrinol. 9: 1223-1232.

Riddle, O., R.W. Bates, and S.W. Dykshorn. 1933. The preparation, identification and assay of prolactin-a hormone of the anterior pituitary. Am. J. Physiol. 105: 191-216.

Robinson, G.W. and L. Hennighausen. 1997. Inhibins and activins regulate mammary epithelial cell differentiation through mesenchymal-epithelial interactions. Development 124: 2701-2708.

Sakakura, T. 1987. M ammary embryogenesis. In The mammary gland: Devel opment, regulation, and function. (ed. M.C. N eville and C.W. Daniel), pp. 37-66. Plenum Press, N ew York, NY.

- - - 1991. N ew aspects of stromal-parenchyma relations in mammary gland differentiation. Intl. Rev. of Cytol. 125: 165-202.

Schaapveld, R.Q.J., J.T.G. Schepens, G.W. Robinson, J. Attema, F.T.T.J. Oerlemans, J.A.M. Fransen, M. Streuli, B. Wieringa, L. Hennighausen, and W.J.A.J. Hendriks. 1997. Impaired mammary gland development and function in mice lacking LAR receptor-like tyrosine phosphatase activity. Dev. Biol. 188: 134-146.

Sicinski, P., J.L. Donaher, S.B. Parker, T. Li, A. Fazeli, H. Gardner, S.Z. Haslam, R.T. Bronson, S.J. Elledge, and R.A. Weinberg. 1995. CyclinD1 provides a link between development and oncogenesis in the retina and breast. Cell 82: 621-630.

Spemann, H. 1901. Entwicklungsphysiologische Studien am Triturus-Ei. Arch. Entw. Mech. Org. 12: 244-264.

Stricker, P. and R. Grueter. 1928. Action du lobe anterieur de I'hypophyse sur la montee laiteuse. Compt. Rend. Soc. Biol. 99: 1978-1980.

Topper, Y.J. and C.S. Freeman. 1980. Multiple hormone interactions in the developmental biology of the mammary gland.
Physiol. Rev. 60: 1049-1056.

Toscani, A., R.V. M ettus, R. Coupland, H. Simpkins, J. Litvin, J. Orth, K.S. Hatton, and E.P. Reddy. 1997. Arrest of spermatogenesis and defective breast development in mice lacking A-myb. Nature 386: 713-717.

Udy, G.B., R.P. Towers, R.G. Snell, R.J. Wilkins, S.-H. Park, P.A. Ram, D.J. Waxman, and H.W. Davey. 1997. Requirement of Stat5b for sexual dimorphism of body growth rates and liver gene expression. Proc. Natl. Acad. Sci. 94: 7239-7244.

Vainio, S. and U. Mueller. 1997. Inductive tissue interactions, cell signaling, and the control of kidney organogenesis. Cell 90: 975-978.

Vale, W., L.M. Bilezikjian, and C. Rivier. 1994. Reproductive and other roles of inhibins and activins. In The physiology of reproduction. (ed. E. Knoblich and J.D. N eilI), pp. 1861-1878. Raven Press, N ew York, NY.

Wagner, K.-U., W.S. Young III, X. Liu, E. Ginns, M. Li, P.A. Furth, and L. Hennighausen. 1997a. Oxytocin and milk re moval are required for post-partum mammary gland development. Genes Funct. 1: 233-244.

Wagner, K.-U., R.J. Wall, L. St-Onge, P. Gruss, L. Garrett, A. Wynshaw-Boris, M. Li, P.A. Furth, and L. Hennighausen. 1997b. Cre-mediated gene deletion in the mammary gland. Nucleic Acids Res. 25: 4323-4330.

Young, S.W., E. Shepard, J. Amico, L. Hennighausen, K.-U. Wagner, M.E. LaM arca, C. M cKinney, and E.I. Ginns. 1996. De ficiency in mouse oxytocin prevents milk ejection, but not fertility or parturition. J. Neuroendocrinol. 8: 847-853.

Zwijsen, R.M.L., E. Wientjens, R. Klompmaker, J. van der Schman, R. Bernards, and R.J.A.M. Michalides. 1997. CDKindependent activation of estrogen receptor by cyclin D1. Cell 88: 405-415. 


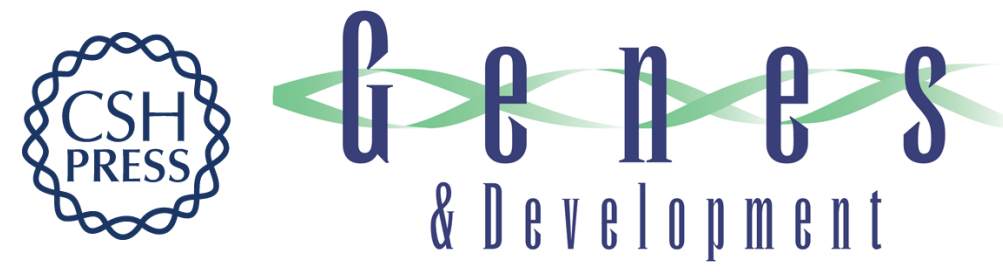

\section{Think globally, act locally: the making of a mouse mammary gland}

Lothar Hennighausen and Gertraud W. Robinson

Genes Dev. 1998, 12:

References This article cites 31 articles, 13 of which can be accessed free at: http://genesdev.cshlp.org/content/12/4/449.full.htmI\#ref-list-1

License

Email Alerting Receive free email alerts when new articles cite this article - sign up in the box at the top Service right corner of the article or click here.

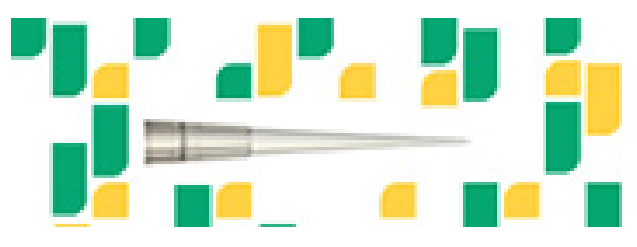

Focused on your science. 